\title{
The Factors that Affecting on the Consumers' Continuing to Use Internet Services in the Banking Industry: Empirical Evidence from Abu Dhabi, UAE
}

\author{
Anas Ali Al-Qudah ${ }^{1}$ \\ ${ }^{1}$ Emirates College of Technology, ECT, Abu Dhabi, UAE \\ Correspondence: Anas Al-Qudah, Emirates College of Technology, ECT, Abu Dhabi, Banking and Finance \\ Department, Millennium Tower, Sheikh Hamdan Street, P. O. Box: 41009, Abu Dhabi, United Arab Emirates. \\ E-mail: anas.alqudah@ect.ac.ae (ORCID ID: orcid.org/0000-0003-3609-1541)
}

Received: January 13, 2017

Accepted: January 25, 2017

Online Published: February 8, 2017

doi:10.5539/mas.v11n4p45

URL: http://dx.doi.org/10.5539/mas.v11n4p45

The research is financed by (Emirates College of Technology, Abu Dhabi).

\begin{abstract}
The aim of the current study is to discover and examine the factors that affecting consumer's and dealers' in banking services to continue using internet banking (electronic services) in United Arab Emirates. one of the most important goal in the banking sectors is a new customer acquisition, but actually the measures of continued the new customer with the bank is more important, that called in the marketing science 'retaining customers'. And one of the most effective methods to do that is make the electronic services more attractive to customers and accorded more attention to the internet banking, to make it understandable and enforceable by any customer. The current study is a natural reaction to a gap in the current references and researches which needed the produce of more unified theoretical analysis and the determination of factors that affect the continuing using of internet banking in the regard of importance to consumers, customers, and banking dealers.

The researcher trying through this study to offer a many concepts depend on theoretical models regarding to the assenting of technology that used in banking industry and circulate of creative theories in this field. The Virtual model of this study includes some variables were created by the main factors from the researcher point eye view depend on some literature was taken in consideration, these factors: Technology, channel and social factors, which effect on the customers through continuing using of internet banking. And in the regarding of Data collection, it was collected using a questionnaire was contributed in Marina mall in Abu Dhabi mall (http://www.marinamall.ae/). A sample of this study includes 292 internet banking users. After run regression for this Data by some types analysis methods the researcher used the result of Likert scale, factor clarification and hierarchical multiple analysis, the main result of this study that the factors chosen in the model have a significantly impact on continuing using of internet banking.
\end{abstract}

JEL classification: G20, G21, G24, G30, G31

Keywords: Internet Banking, Channel Factors, Technology Factors, Social Factors continuing Using, Abu Dhabi UAE.

\section{Introduction}

The conventional method of leading many firms has been Transformation during time that to the internet release, speedy technological growth, especially that what happened after financial liberalization, Mergers between the major financial powers (Mia, et al., 2007). Many new firms are harness the technological development seeking to turn out their services much available to customers (Reid \& Levy, 2008). The banking Industry is one such commercial units which using a wide range of Data to make its users be content with it, (Wresch \& Fraser, 2006). The sectors of banking has accomplished which based on the conventional related to price as a significant items for rivalry was a doubtful way to raise earning and mart proportion in the banking sectors (Durkin et al., 2008).

A greater proportion of expenditures undertaken by banking industry that related to the upkeep administrative and managerial expending of branches and their employee in organizations (Daniel, 1999). The Banks begin to 
admit that depending on some elements didn't use the price as long as alternative methods for competition, and to take advantage in competition and reducing cost (Durkin, 2004). As a result, the services industries in the banking sectors have Turn into a very competitive in the past decades (Thornton \& White 2001). In the competitive circumference, outstanding allocation planning in the regarding to be contact with, and transfer production to, the consumer in effective way supply an advantage to the banking industry (Kerem et al., 2003).

Furthermore, consumers are demand more suitability, as reverberate in longer branches opening times and a raise in the options of service surrender techniques. On the international level, some of institutions in the banking sector have begun to put new strategies to introduce alternative methods regarded to the cost raising (Shih \& Fang 2004). Using the best methods derived from technology in services has made a huge influencing between them in the interest of consumers, moreover to raising calibration of many services (Liljander et al., 2006). The introduction of modern service delivery channels raises the productivity and merit of the supplier of service far from introducing access to customers, that way better gathering customer demand and increasing the gratification of customers (Walker et al., 2002).

In the last few years, witnessed increasing in the Internet Banking using to a large extent, which indicates the massive kind of bargain hold by internet banking users (Kasheir et al., 2009). This special idea and utilize of internet banking, jointly with using internet, amends the conduct of persons across this type of items "channel" (Gefen et al., 2003). Modification is apparent in customer's prior understanding and raises the requirements to grasp not before the consumers accepting attitude, but after accepting actions too (Yu et al., 2005). Newly the investigators in the banking services have begin to understand the value of consumers' using of internet banking and its effect in the economics rendering of the banking sector (Kasheir et al., 2009). Continuing using of the internet in the banking sector by consumers didn't has a sufficient studying by economics researchers and some of studies coverage consumer accepting to use it and approbate of using these banking services (Eriksson \& Nilsson, 2007). In according to gain new purchaser, using the internet banking is regarding to a cost-effective planning which aims to retain the consumers. The purpose of any firm in the long run is to maximize its output and make earnings. The planning of Retention encourages minimize customers' convert attitude (Kasheir et al., 2009).

\section{Literature Review}

All researchers agree that the Consumers' continuing using of internet banking estimation may be very complex more than the theories which explain that, because of the fact that consumers or customers often want to let down or decrease their present attitude and their related to technological progress (Falk et al., 2005). In addition, usage depends onto a person' ability, to attract with these services (Walker \& Johnson, 2006). But, continuing using is directly associated with the way of update techniques (Kim \& Malhotra, 2005). Then, current models, however symptomatic of using internet behavior, have not enough imagine in regarding of the factors which customers turn to in the make decision process.

Many decades ago, there was conveying in utility towards SMS-banking (Lockett \& Littler, 1997). Next researches covered banking sector from the internet prospective (Black et al., 2001), the primary focus of attention on the activities engage in community rather than on the conduct of customers (Black et al., 2002). Some studies launch inquiring the value of consumers and their channel interactions and confirm the degree of harmony between a specific service and a channel (Morrison \& Roberts, 1998). Moreover, present research also concentrated on distinguishes factors affecting a consumer's decision to foster a particular channel as well as diverse channels (Bell \& Lyman, 1999).

Several firms are using technological progress in order to turn out their services more attainable to customers as well as to recover their firms' performance and raise their productivity (Reid, 2008). However, the linkage between technological progress and rise in business productivity is handy, only if they are accepted by the targeted users (Venkatesh et al., 2003).

The methodology and the objective of this study are unlike previous in some ways. Mainly, it creates an attempt to focus on customers channel interactions through their post-adoption attitude. And then, channel-related factors are specified as consisting of components such as consumers' comprehension of their self-activity, confidence and personalization. Lastly, the study tries to tests and discovers the effect of these channel factors on customers' continuing using of internet banking. With some reservation to keeping back the study of (Adapa \& Cooksey, 2013).

It is necessary to know what consumers' value for and what the important dimensions are, that play a high role in their ruling of value display. Perceived value appear a consumers' overall estimate of the use depend on understanding of what is received and what is given (Zeithaml, 1988). Understanding value is specific in the 
literature as a trade-off between the understand interests and understand costs derived by the customers from using a specific channel. Monetary outflow and non-monetary sacrifices, such as time consuming and strain experienced by customers, jointly include understand costs (Yang \& Peterson, 2004), whereas, customer grasp value stand out from an estimation of the relative rewards and sacrifices linked with the offering. And the Figure I shows overall framework showing the order in which variables sets will be considered in the forecasting of continuing Using of Internet Banking.

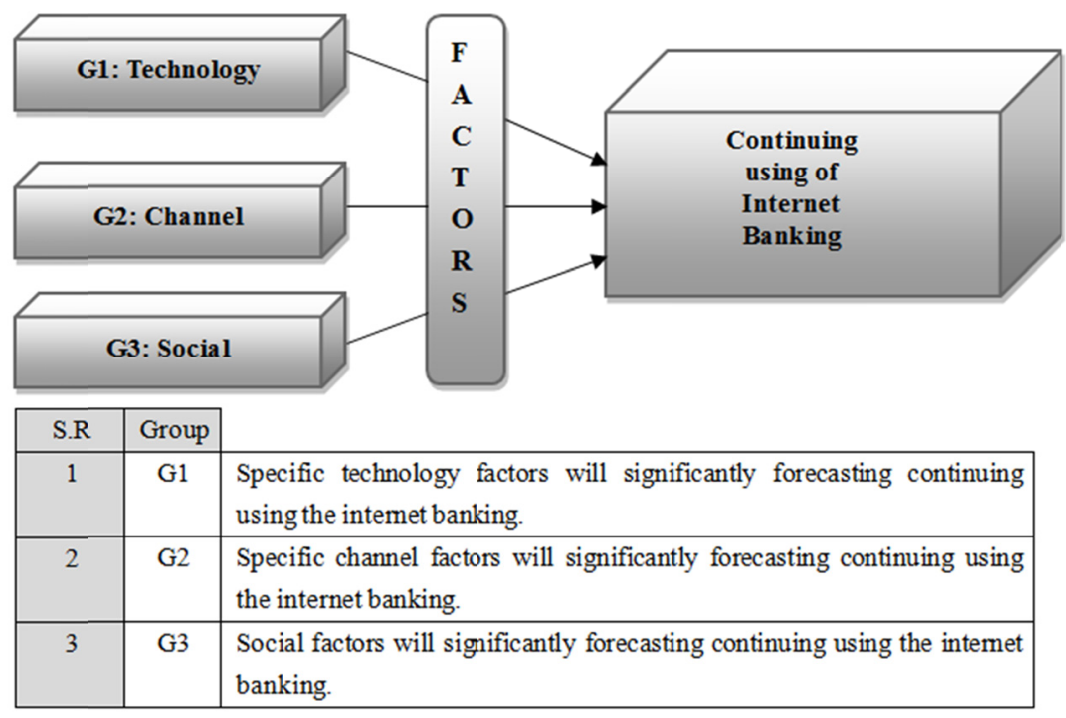

Figure 1. The Virtual Model of the study: shows the Independents Variables \& Dependent variable

\section{Results Methodology}

This study was conducted in the Abu Dhabi area, as it is a capital of Arab economies in Middle East. The questionnaire distributed was in a randomly method, which means the researcher didn't know if the people who take the questionnaires are users or no. Out of the 750 respondents have been met at the entrance of MARINA mall in Abu Dhabi (http://www.marinamall.ae/), 431 respondents answered the questionnaire in that time directly. But only 411 of these questionnaires obtained were valid with complete responses, which indicate $54.8 \%$. Among the 411 questionnaires, 292 with completed by users and residual questionnaires 119 are not using the banking services through the internet. And to achieve the objective of this survey, responses from the users of the banking services through the internet $(\mathrm{N}=292)$ were used in the analysis process.

Depend on the study tool the questions related to respondent's consisted public banking questions, internet usage, characteristics, scale items and other questions, these groups were arranged in a systematic way. And the Questions which linked with public banking conduct, demographic characteristics and internet usage were inserted in the survey unheeding to the respondent's internet banking usage method. The factors that Addressed by this study were handled as the following:

\subsection{Technology}

It included in the current study were operated in a mode harmonic with prior internet banking Literature in other studies situation (Hernandez \& Mazzon, 2007; Chan \& Lu, 2004; Tan \& Teo, 2000; Moore \& Benbasat, 1991). In the current study, these factors were included using 14 sections of 2 different dimensions (Moore \& Benbasat, 1991).

\subsection{Channel}

These Factors were operated in accordance with study of Hernandez \& Mazzon (2007), Chan \& Lu (2004), Tan $\&$ Teo (2000), Rhee \& Riggins (1997), and Lee (1996). Channel factors were measured using the 14 item depend on of 2 different dimensions like understand the self efficacy, understand risk (Hernandez \& Mazzon, 2007; Tan $\&$ Teo, 2000).

\subsection{Social}

These Factors were operated in adapting with the study of Chan \& Lu (2004), Venkatesh \& Davis (2000), and Tan \& Teo (2000). In this study, these factors were measured using the six sections scale consisting of 2 
dimensions individual standard and personal relationship effects.

\subsection{Continuing Using of Internet Banking}

These factors were operated in according with the study of Chan \& Lu (2004), and Venkatesh (2000). And it measured using only 3 scales.

For data collection purpose, respondents who presently internet banking users Responded the survey questionnaire using Likert scale defined as following:

Table 1. Likert scale: a scale used to represent people's attitudes to a specific topic

\begin{tabular}{llllll}
\hline$(1)$ & $(2)$ & $(3)$ & $(4)$ & $(5)$ & $(6)$ \\
\hline Strongly Agree & Agree & Neutral & Disagree & Strongly Disagree & Unable to Rate \\
\hline
\end{tabular}

After researcher obtained the suitable questionnaires for study he did the coding process comprising a code to represent a particular response to a particular question. While, data coding the ensured that all the data were numeric, each variable for each respondent taken the same column in the Statistical Package for the Social Science (SPSS), all the codes identified for a variable were mutually exclusive, each variable was coded in order to obtain maximum input and coding basics were implemented systematically for all users (Cohen et al. 2003). The relevance obtained data from the questionnaires were entered to SPSS 18.0 computer program (SPSS 2015) for the purposes of analysis and get logical results to use it in explain the factors mention above.

\section{Results}

\subsection{Main Items Analysis Results for the Factors of Technology}

The "main items analysis method" and a "rotation" of the technical constraints comprising (14 critical scales) items was manage on a random sample $(\mathrm{N}=292)$ in Abu Dhabi internet banking user as below in Table II. As shown in the Table II that presents the fourteen scale items, after using the "Kaiser-Guttman" retention criterion the correlation refer that two items derived from the technical items to be "positive" correlation (0.49) at a medium level, are frankly well characterize and account for (37.49\%) of the variance.

The two technology factors items were assorted depend on a display of the objective signification of the many scales of their determining items. 'Usability' items composed by of items relating to the customers' range of ease and suitability with internet banking, compatibility with their solitary and their lifestyles and the range to which they could carry the advantage of internet banking usage to the other individuals. 'Trialability' component linked with the extent to which consumers' can seek internet banking indeed or any adds on countenance regarding to internet banking on a restricted base before they really consume these services.

Table 2. Main Items Analysis Result for the Factors of Technology $(\mathrm{N}=292)$

\begin{tabular}{llll}
\hline & Scale Item & Factors & \\
\hline SR & & 1 & 2 \\
\hline $1^{*}$ & Banking transactions will be easier with Internet banking. & 0.57 & \\
$2^{*}$ & My finances will be more control with Internet banking. & 0.73 & \\
$3^{*}$ & Manage my finances will be more managed with Internet banking. & 0.69 \\
$4^{*}$ & Internet banking is a suitable way to manage my finances. & 0.72 \\
$5^{*}$ & Internet banking is harmonious with lifestyles & 0.68 & \\
$6^{*}$ & Using internet banking prepared well with the method that I like to manage & 0.73 & \\
$7^{*}$ & my Accounts & 0.79 & \\
$8^{*}$ & Internet banking is harmonious with my working style & 0.44 & \\
$9^{*}$ & My financial resources managed well with Internet banking. & 0.51 & \multirow{2}{*}{0.89} \\
$10^{* *}$ & Internet banking is available for me all the time. & 0.79 \\
$11^{* *}$ & I can use internet banking to check what it can do for me before the actual & & 0.71 \\
\hline $12^{* *}$ & adoption. & & \\
$13^{*}$ & I think many offers to try internet banking before the actual Adoption. & & \\
\hline
\end{tabular}




\begin{tabular}{llll}
\hline $14^{*}$ & It's easy to explain to others to how using internet banking. & 0.49 \\
$14^{*}$ & It's easy to explain to others to how using internet banking. & 0.49 & \\
\hline Eigenvalues & 3.82 & 1.98 \\
KMO & 0.71 & \\
Bartlett's test of Sphericity & $\mathrm{p}<0.001$ & \\
\hline Correlation & & Factor 2 \\
& & 0.49 \\
Factor 1 & Factor1 & 1.00 \\
Factor 2 & 1.00 & 0.49 & \\
\hline
\end{tabular}

*(Usability), ${ }^{* *}$ (Trialability)

\subsection{Main Items Analysis Output for the Factors of Channel}

The "main items analysis method" and a "rotation" of the Channel constraints comprising (14 critical scales) items was manage on a random sample $(\mathrm{N}=292)$ in Abu Dhabi internet banking user as below in Table III. As shown in the Table III that presents the fourteen scale items, after using the "Kaiser-Guttmann" retention criterion the component correlation refer that two components derived from the Channel factors to be "positive" correlation (0.44) at a medium level, are frankly well characterize and account for (33.39\%) of the variance. The two Channel factors items were assorted depend on a display of the objective signification of the many scales of their determination scales. 'Safety' items related to the safely of internet banking. 'Specialty' items are related to the specialization items by the consumers as unrivaled and special consumers due to their attitude of carry out internet banking.

Table 3. Main Items Analysis Result for the Factors of Channel $(\mathrm{N}=292)$

\begin{tabular}{|c|c|c|c|}
\hline & Scale Item & Factors & \\
\hline SR & & 1 & 2 \\
\hline $1^{*}$ & No need to anyone to show me how to use internet banking. & 0.72 & \\
\hline $2 * *$ & $\begin{array}{l}\text { It's more easy if I have the "play-store" online to help function to learn the using } \\
\text { internet banking. }\end{array}$ & & 0.59 \\
\hline $3 *$ & I can use internet banking even if I have only the online instructions for assistance. & 0.59 & \\
\hline $4 * *$ & I can use internet banking without to see anyone else using it before me. & & 0.69 \\
\hline $5 * *$ & I can use internet banking if I call someone to help me. & & 0.77 \\
\hline $6^{*}$ & I think that using internet banking in Abu Dhabi is safe & 0.57 & \\
\hline $7 *$ & My internet banking transactions cannot be accessed by others in Abu Dhabi. & 0.41 & \\
\hline $8^{*}$ & Using Internet banking lead me to an efficient use of my time. & 0.59 & \\
\hline $9^{*}$ & Internet banking is very dependable. & 0.72 & \\
\hline $10^{*}$ & My privacy is protected when I using internet banking & 0.67 & \\
\hline $11^{*}$ & Using internet banking is financially safe & 0.63 & \\
\hline $12 * *$ & The internet banking give me impression that I'm a good consumer & 0.42 & \\
\hline $13 * *$ & Internet banking provides information that is designer-made for me. & & 0.57 \\
\hline \multirow[t]{6}{*}{$14 * *$} & The offers that I read it through internet banking transactions are attainable to me. & & 0.47 \\
\hline & Eigenvalues & 3.42 & 1.89 \\
\hline & KMO & 0.72 & \\
\hline & Bartlett's test of sphericity & $\mathrm{p}<0.001$ & \\
\hline & Correlation & & \\
\hline & Factor1 & Factor 2 & \\
\hline Factor & 1.00 & 0.44 & \\
\hline 1 & & & \\
\hline Factor & 0.44 & 1.00 & \\
\hline 2 & & & \\
\hline
\end{tabular}

\subsection{The Main Items Analysis Output for the Factors of Social}

The outcome which gained from the Main Items Analysis Output for the Factors of Social in Table IV, The 
Kaiser-Guttmann possession criteria of Eigenvalues greater than one provided the pure derived of a 1 item solution. The eventual single component accounted for 54.62 of variance.

Table 4. Main Items Analysis Result for the Factors of Social $(\mathrm{N}=292)$

\begin{tabular}{lc}
\hline Items & Factor \\
\hline I can observe how others make their banking transactions before I actually make my & 0.49 \\
transactions. & 0.69 \\
I can check with others that I am duly using internet banking. & 0.79 \\
I'm trying to collect some information from friends before I make any banking transactions & 0.60 \\
Usually My opinion to implement internet banking is affected by my colleagues & 0.73 \\
Usually My opinion to implement internet banking is affected by my family & 0.62 \\
Usually My opinion to implement internet banking is affected by my friends & 3.77 \\
\hline Eigenvalues & 0.79 \\
KMO & $\mathrm{p}<0.001$ \\
\hline
\end{tabular}

Main Items Analysis Output for the Factors of Social derive outcome in an of a single item consisting of the scale items related to the effect extend on the customer to use internet banking by the colleagues, friends and family members

\subsection{Main Items Analysis Output for the Factors of continuing using of Internet Banking}

Table V shows Main Items Analysis Output for the Factors of continuing using measure. The Kaiser-Guttmann retention criterion of Eigenvalues greater than one provided the pure derived of a one-component solution. The eventual single component accounted for $(59.42 \%)$ of variance

Table 5. Main Items Analysis Output for the Factors of continuing using of Internet Banking $(\mathrm{N}=292)$

\begin{tabular}{ll}
\hline Items & Factor \\
\hline I looking to exceed the using of internet banking in future & 0.49 \\
The Internet banking usage consider a positive experience & 0.59 \\
I plan to use internet banking systematically in my banking transactions & 0.56 \\
Eigenvalues & 1.92 \\
KMO & 0.69 \\
Bartlett's test of sphericity & $\mathrm{p}<0.001$ \\
\hline
\end{tabular}

\subsection{Cronbach's Alpha To Test: Reliability Analysis}

The researcher used Cronbach's alpha to test internal consistency reliability, in this type of this studies around 0.60 at least (Graham 2006). And the result of the reliability statistics in this study identified main factors analyses are presented in Table VI

Table 6. Reliability Statistics

\begin{tabular}{llll}
\hline Variable & Scale & Number of & Cronbach's \\
\hline Technology factors & & Items & Alpha \\
& Usability & $11: 14$ & 0.71 \\
& Trialability & $3: 14$ & 0.65 \\
\hline Channel factors & Safety & $8: 14$ & 0.63 \\
& Specialty & $6: 14$ & 0.60 \\
\hline Social factors & ------- & $6: 6$ & 0.69 \\
\hline continuing using factors & ------- & $3: 3$ & 0.62 \\
\hline
\end{tabular}

The important objective in this study is to make judge and forecasting for the customers ability to be continuing using of internet banking to impact a particular order of Independent variables groups, the researcher identified before in Figure I, as Technology, Channel and Social Factors, and the continuing using factors was a Dependent 
Variable. Such an objective is optimally hierarchical multiple statistical method of analysis has been suited to this regression (Cooksey 2007).

Table VII shows the independent variable Groups and their main items in the order in which the groups would be getting in to the hierarchical regression model. Data intended to be presented to hierarchical regression were gained from computed average on the two main items of technology factors, two main items of channel factors, one item of social factors

Table 7. Variable Groups and their main items Contained in Hierarchical Regression

\begin{tabular}{ll}
\hline Variable sets & Scales \\
\hline Technology factors & Usability \\
& Trialability \\
\hline Channel factors & Safety \\
& Specialty \\
\hline Social factors & Social \\
\hline
\end{tabular}

\subsection{The Model of Estimation the Continuing Using of Internet Banking}

The (multiple) regressions were run to analyses for the impact the independent variable (Technology, Channel and Social Factors) groups in forecasting the continuing using of internet banking as a group the dependent variable. Table VIII shows the $\mathrm{R}^{2}$ variation and freedom degrees for all groups, the $\mathrm{F}$ variation (F-test) and related $\mathrm{p}$-value.

The researcher used Durbin-Watson test for the existence of correlation between (residuals). This requires that the residuals in forecasting do not follow a modality shape from group to other (Meyers et al. 2006). As a general rule the (residuals) are not correlated if the Durbin-Watson test result is around (2), and an acceptable range is (1.49-2.49), (Wilcox 1997). For the current study, the Durbin-Watson result is (2.20) which mean within the acceptance numbers.

Also, Table VIII shows in the hierarchical multiple analyses with three models. At the end of each model $\mathrm{R}^{2}$ was significantly away from zero. And in all the independents variables groups in the equation the overall regression analysis model was significant because $\left(\mathrm{R}^{2}=0.48, \mathrm{R}^{2}\right.$ - adjusted $=0.39, \mathrm{~F}=21.33$, and, $\left.\mathrm{p}<0.001\right)$. So all independents variables groups which entered explained around (adjusted- $\mathrm{R}^{2}: 45 \%$ ) of variance in the dependent variable, mean continuing using of internet banking.

Table 8. Multiple Regression Model Analysis

\begin{tabular}{|c|c|c|c|c|c|c|c|c|c|}
\hline Model & Variable & $\mathrm{R}^{2}$ & $\mathrm{Df}$ & $\mathrm{F}$ & Sig. F & Variable & $\mathrm{SR}^{2}$ & Partial- F & Sig. \\
\hline \multirow[t]{3}{*}{1} & Technology & 0.19 & 2 & 45.77 & $\begin{array}{l}< \\
0.001 *\end{array}$ & Usability & 0.35 & 11.44 & $\begin{array}{l}< \\
0.001 *\end{array}$ \\
\hline & Factors & & & & & & & & \\
\hline & & & & & & Trialability & 0.21 & 4.88 & $\begin{array}{l}< \\
0.001^{*}\end{array}$ \\
\hline \multirow{2}{*}{2} & Channel & 0.16 & 2 & 35.34 & $<$ & Safety & 0.19 & 7.79 & $<$ \\
\hline & Factors & & & & $0.001 *$ & Specialty & 0.11 & 6.89 & $\begin{array}{l}0.001 * \\
< \\
0.001 *\end{array}$ \\
\hline 3 & Social Factors & 0.17 & 1 & 10.22 & $0.001 *$ & & & & \\
\hline $\begin{array}{l}\text { Overal } \\
\mathrm{R}^{2}-\text { ad } \\
0.05<\end{array}$ & $\begin{array}{l}\text { odel } \mathrm{R}^{2}=0.48 \\
\text { ted }=0.45, \mathrm{~F}= \\
0.10 \text { considere }\end{array}$ & 3 & & & & & & & \\
\hline
\end{tabular}

In the table above we can conclude from first Model (regarding Technology), the technology factors forecasting significantly of continuing using of internet banking $\left(\mathrm{R}^{2}=0.19, \mathrm{~F}=45.77, \mathrm{p}<0.001\right)$, so this independent variable which entered explained around (19\%) of variance in the dependent variable continuing using of internet banking. But in the second Model, (regarding Channel), the channel factors forecasting significantly of continuing using of 
internet banking $\left(\mathrm{R}^{2}=0.16, \mathrm{~F}=35.34, \mathrm{p}<0.001\right)$, so this independent variable which entered explained around $(16 \%)$ of variance in the dependent variable continuing using of internet banking. And in third Model (regarding Social), the social factors forecasting significantly of continuing using of internet banking $\left(R^{2}=0.17, F=10.22, p\right.$ $<0.001)$, so this independent variable which entered explained around $(17 \%)$ of variance in the dependent variable continuing using of internet banking.

Table 9. Hypotheses Testing Results

\begin{tabular}{ll}
\hline Hypothesis & Result \\
\hline $\mathrm{H}_{1}$ : Technology factors are significantly forecasting to the continuing using of internet & $\begin{array}{l}\text { Significantly } \\
\text { banking. }\end{array}$ \\
$\mathrm{H}_{1 \mathrm{~A}}$ : Usability as item of the technoling \\
using of internet banking. & $\begin{array}{l}\text { Significantly } \\
\text { forecasting }\end{array}$ \\
$\mathrm{H}_{1 \mathrm{~B}}$ : Trialability as item of the technology factors are significantly forecasting to the & $\begin{array}{l}\text { Significantly } \\
\text { continuing using of internet banking. }\end{array}$ \\
$\mathrm{H}_{2}$ : Channel factors are significantly forecasting to the continuing using of internet banking. & Significantly \\
& forecasting \\
$\mathrm{H}_{2 \mathrm{~A}}$ : Safety as item of the channel factors are significantly forecasting to the continuing using & $\begin{array}{l}\text { Significantly } \\
\text { of internet banking. }\end{array}$ \\
$\mathrm{H}_{2 \mathrm{~B}}$ : Specialty as item of the channel factors are significantly forecasting to the continuing & $\begin{array}{l}\text { Significantly } \\
\text { using of internet banking. }\end{array}$ \\
$\mathrm{H}_{3}:$ Social factors are significantly forecasting to the continuing using of internet banking. & Significantly \\
& forecasting \\
\hline
\end{tabular}

\section{Discussion the Results}

The results of this study show that the researcher Accept all main Hypotheses, and the sub-Hypothesis, and it's clear from the Table IX that the $\mathrm{R}^{2}$ for the model as a whole reached to (adjusted $\mathrm{R}^{2}=45 \%$ ), statistically this result means that the model which was used explained around $(45 \%)$ of changes which happened in the variables.

Moreover, statistically the Independent Variables were used in the model mentioned before in the Figure I, (Social factors, Channel factors and Technology factors) with each other can explain approximately fifty percent from the changes which happened in the Dependent Variable (continuing using of internet banking). But when we talk about the Independent Variables separately we will find that the 1st Independent variable (Technology factors) can explain (19) percent from the changes which happened in the Dependent Variable (continuing using of internet banking), moreover, the 2nd Independent variable (Channel factors) can explain (16) percent from the changes which happened in the Dependent Variable (continuing using of internet banking), and the 3rd Independent variable (Social factors) can explain (17) percent from the changes which happened in the Dependent Variable (continuing using of internet banking).

According to the main objective in this study that was to make judge and forecasting for the customers ability to be continuing using of internet banking to impact a particular order of Independent variables groups (Social factors, Channel factors and Technology factors), the researcher found that there are a Positive impact between the Dependent Variable \& the Independent Variables. Moreover, the (F) values appear in Table VIII shows that all the variables together have significantly forecasting to the continuing using of internet banking. And each one of the model variable separately has have significantly forecasting to the continuing using of internet banking too.

The researcher believes that it is appropriate to refer to the study of (Adapa, Cooksey, 2013) which conducted in Australia (Western Sydney region), because the results of the (Adapa, Cooksey, 2013) study were somewhat different especially in the Social factors as an independent variable, but the results of the current study is compatible with almost previous studies.

\section{Acknowledgments}

Researcher thanks all parties that supported this work, especially Emirates College of Technology, ECT, and all people who responded to the questionnaire and the Scholars who achieved the questionnaire arbitration. 


\section{References}

Adapa, S., \& Cooksey, R. (2013). Factors affecting consumer's continued use of internet banking: Empirical Evidence from Australia. Australasian Journal of Information Systems, 18(1), 5-31.

Bell, G., \& Lyman, M. M. (1999). Buying financial services: A model including the channel effect. Academy of Marketing Conference, Stirling.

Black, N. J., Lockett, A., Ennew, C., Winklhofer, H., \& McKechnie, S. (2002). Modelling consumer choice of distribution channels: An illustration from financial services. International Journal of Bank Marketing, 20(4), 161-173. http://dx.doi.org/10.1108/02652320210432945

Chan, S., \& Lu, M. (2004). Understanding internet banking adoption and use behaviour: A Hong Kong Perspective. Journal of Global Information Management, 12(3), 21-43. http://dx.doi.org/10.4018/jgim.2004070102

Cohen, J., Cohen, P., West, S., \& Aiken, L. 2003, Applied Multiple Regression/ Correlation Analysis for the Behavioural Sciences (3rd ed.). Lawrence Erlbaum Associates, Mawah, New Jersey.

Cooksey, R. W. (2007). Illustrating statistical procedures: For business, behavioural \& social science research (1st ed.). Tilde University Press, Australia.

Daniel, E. (1999). Provision of electronic banking in the UK and the Republic of Ireland. International Journal of Bank Marketing, 17(2), 72-82. http://dx.doi.org/10.1108/02652329910258934

Desouza, K. C., Awazu, Y., \& Ramaprasad, A. (2007). Modifications and innovations to technology artefacts. Technovation, 27, 204-220. http://dx.doi.org/10.1016/j.technovation.2006.09.002

Duncan, C., \& Dennis, H. (2004). Kaiser-Guttman criterion In: The SAGE Dictionary of Statistics, Print ISBN: 9780761941378, Online ISBN: 9780857020123. http://dx.doi.org/10.4135/9780857020123.n276

Durkin, M. (2004). In search of the internet banking customer, exploring the use of decision styles. International Journal of Bank Marketing, 22(7), 484-523.

Durkin, M., Jennings, D., Mulholland, G., \& Worthington, S. (2008). Key influencers and inhibitors on adoption of the internet for banking. Journal of Retailing and Consumer Services, 15, 348-357. http://dx.doi.org/10.1016/j.jretconser.2007.08.002

Eriksson, K., \& Nilsson, D. (2007). Determinants of the continued use of self-service technology: The case of internet banking. Technovation, 27(4), 159-167.

Graham, J. M. (2006). Congeneric and (essentially) equivalent estimates of score reliability: What they are and how to use them? Educational and Psychological Measurement, 66, 930-944. http://dx.doi.org/10.1177/0013164406288165

Hernandez, J. M. C., \& Mazzon, J. A. (2007). Adoption of internet banking: Proposition and implementation of an integrated methodology approach. International Journal of Bank Marketing, 25(2), 72-88.

Kasheir, D., Ashour, A. S., \& Yacout, O. M. (2009). Factors affecting continued usage of internet banking among Egyptian customers. Communication of the IBIMA, 9, ISSN: 1943-7765.

Kerem, K., Lustsik, O., Sorg, M., \& Vensel, V. (2003). The development of e-banking in a EU candidate country: An Estonian case. Proceedings of International Atlantic Economic Society Conference, Vienna, March 11-17.

Kim, S. S. \& Malhotra, N. K. (2005). A longitudinal model of continued IS use: An integrative view of four mechanisms underlying post adoption phenomena. Management Science, 51(5), 741-755.

Lee, E., Lee, J. \& Eastwood, D. (2003). A two-step estimation of consumer adoption of technology-based service innovations. The Journal of Consumer Affairs, 37(2), 256-282.

Liao, S., Shao, Y. P., Wang, H., \& Chen, A. (1999). The adoption of virtual banking: An empirical study. International Journal of Information Management, 19, 63-74.

Liljander, V., Gillberg, F., Gunmerus, J., \& Riel, A. V. (2006). Technology readiness and the evaluation and adoption of self-service technologies. Journal of Retailing and Consumer Services, 13, 177-191.

Lockett, A. \& Littler, D. (1997). The adoption of direct banking services. Journal of Marketing Management, 13, 791-811.

Mia, M. A. H., Rahman, M. A., \& Uddin, M. M. (2007). E-Banking evolution, status and prospects. The Cost 
and Management, 35(1), 36-48.

Moore, G. C., \& Benbasat, I. (1991). Development of an instrument to measure the perceptions of adopting an information technology. Information Systems Research, 2(3), 173-191.

Morrison, P. D., \& Roberts, J. H. (1998). Matching electronic distribution channels to product characteristics: The role of congruence in consideration set formation. Journal of Business Research, 41(3), 223-229. http://dx.doi.org/10.1002/dir.20079

Reid, M., \& Levy, Y. (2008). Integrating trust and computer self-efficacy with technology acceptance model: An empirical assessment of customers' acceptance of banking information systems (BIS) in Jamaica. Journal of Internet Banking and Commerce, 12(3). Retrieved 15th April, 2009, from http://www.arraydev.com/commerce/jibc

Rhee, H. S., \& Riggins, F. (1999). GVU's WWW user surveys: High level summary of internet banking survey. Retrieved 10th December, 2009, from http://www.gvu.gatech.edu/user-survey/survey-1997-04/graphs/banking/report.html

Rugimbana, R. (1995). Predicting automated teller machine usage: The relative importance of perceptual and demographic factors. International Journal of Bank Marketing, 13(4), 26-32. http://dx.doi.org/10.5539/ass.v11n26p217

Rust, R. T., \& Espinoza, F. (2006). How technology advances influence business research and marketing strategy. Journal of Business Research, 59, 1072-1078. http://dx.doi.org/10.1016/j.jbusres.2006.08.002.

Shih, Y., \& Fang, K. (2004). The use of decomposed theory of planned behavior to study internet banking in Taiwan. Internet Research, 14. http://dx.doi.org/10.1108/10662240410542643

\section{Copyrights}

Copyright for this article is retained by the author(s), with first publication rights granted to the journal.

This is an open-access article distributed under the terms and conditions of the Creative Commons Attribution license (http://creativecommons.org/licenses/by/4.0/). 